IJCCS (Indonesian Journal of Computing and Cybernetics Systems)

Vol.13, No.3, July 2019, pp. 283 292

ISSN (print): 1978-1520, ISSN (online): 2460-7258

DOI: https://doi.org/10.22146/ijccs.47275

\title{
Digitalization On Students Scoring System of SMPN 18 Bekasi
}

\author{
Fesa Asy Syifa Nurul Haq ${ }^{* 1}$, Nuryuliani \\ ${ }^{1}$ Master Program of Technology and Engineering, Universitas Gunadarma, Jakarta, Indonesia \\ ${ }^{2}$ Universitas Gunadarma, Jakarta, Indonesia \\ e-mail: *1․ fesasyifa2007@gmail.com, ${ }^{2} \underline{\text { nryulia@ staff.gunadarma.ac.id }}$
}

\begin{abstract}
Abstrak
Teknologi informasi telah mendukung pengembangan kualitas jasa pelayanan sekolah di seluruh dunia. Namun masih banyak sekolah yang belum memanfaatkannya secara optimal khususnya di Indonesia, contohnya di SMPN 18 Bekasi. Seperti pada umumnya sekolah hanya menggunakan aplikasi Ms.Word dan Ms. Excel. Hal itu mengakibatkan terjadinya perbedaan format penilaian dan kesalahan saat mengisi nilai ke dalam format rapot. Aplikasi sistem informasi akademik yang dikembangkan dalam penelitian ini menggunakan bahasa pemrograman PHP, HTML, dan MYSQL ini diberi nama SIADHEL yang artinya sistem informasi akademik delapan belas. Tujuan pembuatan aplikasi ini ialah agar siswa/orangtua siswa dapat menerima informasi penilaian sekolah secara tepat, cepat dan akurat. Para guru juga dapat menggunakan fasilitas dalam mengolah nilai siswa sehingga terintegrasi dan teringkas dengan baik sebagai data bagi Kepala Sekolah untuk membuat kebijakan. Aplikasi ini dapat dibuka pada platform browser apa saja, sehingga memudahkan pengguna untuk mengaksesnya dimana saja dan kapan saja.
\end{abstract}

Kata kunci-Aplikasi, Sistem Informasi Akademik, Website

\begin{abstract}
Information technology has been supporting the development of school services in the world. But there are still many schools does not using the information technology at all specially in Indonesia, for example at SMPN 18 Bekasi. As usually like another school they only using Ms. Word and Ms. Excel applications. That is make many differences output in format scoring and mistakes while filling score on the students report format. The application of academic information system in this research have developed using PHP, HTML and MySQL as programming language. It named SIADHEL, means Eighteen Academic Information System (Sistem Informasi Akademik Delapan Belas). The aims of this project is to provide a good tools for students or their parents to receive the exactly, fast and accurate informations of their students scoring. Teachers can use an integrated and accurate tools as facility to provide data for the Principal to make new policies. This application could be opened by every browser platform, so it will make easier for the users to access the program wherever and anytime.
\end{abstract}

Keywords - Application, Academic Information System, Website

Received July $3^{\text {rd }}, 2019 ;$ Revised July $18^{\text {th }}$, 2019; Accepted July $30^{\text {th }}, 2019$ 


\section{INTRODUCTION}

Information technology has supported the development of school services in the world. But there are still many schools does not using the information technology at all - specially in Indonesia, for example at SMPN 18 Bekasi. Commonly like another school they only using Ms. Word and Ms. Excel applications. That is make many differences output in format scoring and some mistakes while filling the score on the students report format.

Those applications which are used to make a student scoring is not integrated yet. As we know today almost every school using 2013 Curriculum or namely K-13 (1). It is difficult for the teachers to fill the scoring format of the students reports. So it would make many mistakes because of it's different scoring methods. The diference between application file of the class teachers and subject teachers make some difficulties when they fill the score to the report format, it will take more time on making the students report.

Moreover, in making a report on the results of the students scoring also take quite longer because it needs to be rearranged the report given by the class teachers. This caused the academic information should be late at the students hands when needed [2]. There have been many studies that discuss about the development and utilization of academic information system in the processing of the student scoring in the high school and university. In the scope of high school and vocational school, the studies have done by Farid who developed an academic information specially in the valuation of high school students using the R \& D method [2], then by Recky designed the academic information system at the high school [5]. Muhammad Ali also designed an information systems at the school of Madrasah Aliyah [7]. All of their design used the waterfall method. Other studies conducted in the university level has done by Yan, which is did the research regarding to design and implementation in STAI used SDLC method [3], then Kurniadi has researched in development of student academic services section [4], and Mulyani did about student activities participation on credit system [8]. It is still rarely research on development or utilization of academic information system by the web in the first level of secondary schools.

From the previous research, almost all web-based. With a web-based academic information systems can be accessed easily and can use various browsers that exist on the computer or smartphone [3]. The existence of this academic information system as a support of academic services will provide satisfying services on the scoring processing, reliable and affordable [4]. This is due to more web-based, easy to learn and easier to be developed further. In a web is also required to use another languages in order to make the data flow processing, including to use languages such as PHP, MySQL is one of the DMBS which can be used by multiusers and multithread [5]. According to the study, MySQL occupies second rank from a variety of relational databases, this is because the use of MySQL easier and can be learned directly $[6,7,8]$.

\section{METHODS}

\subsection{Metode Penelitian}

In this study, the first activity undertaken is obtaining data and information concerning to the score processing of the students through interviews and several ministerial regulations about the scoring system is based on level of education. The methods used in the development of the system includes several stages presented on Figure 1.

IJCCS Vol. 13, No. 3, July 2019 : 283 - 292 


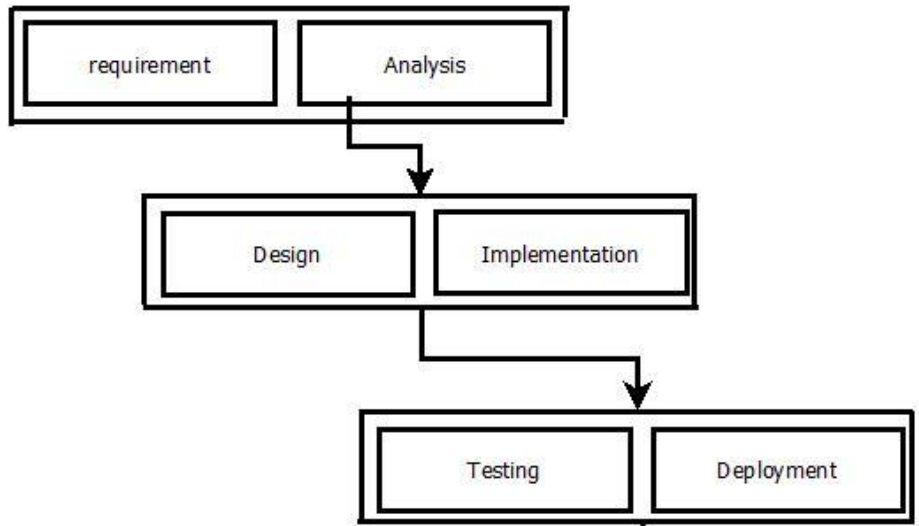

Figure 1 System development stage

Based on PerMenDikBud No. 23 Year 2016 [1], the student assessment consists of three aspects:

1. Aspects of Attitude Assessment aspects of attitudes is done through observation that the responsibility is in the hand of the class teachers.

2. Aspects of Knowledge

Assessment aspect of knowledge is done through written tests, oral tests, and assignments in accordance with the competencies assessed.

3. Aspects of Skills

Assessment was undertaken through the skills aspect of the practices, products, projects, portfolios, and other techniques in accordance with the competencies assessed.

Based on these three aspects, aspects of knowledge or skills have it's calculation used by the school SMPN 18 Bekasi as the following equation:

$$
\begin{aligned}
& \bar{X}_{\text {competency }}=\text { Written }+ \text { Observation }+ \text { Assignment } \\
& N_{\text {competency }}=\mid \bar{X}_{\text {competency }} \geq(\text { KKM }) \mid \\
& \overline{N H}=\sum_{n=1}^{6}\left(\bar{X}_{\text {competency }}\right)_{n} \\
& \text { Total scoring }=(\overline{N H} * \text { value } N H)+\left(N_{U T S} * \text { value UTS }\right)+\left(N_{U A S} * \text { value UAS }\right) \\
& \bar{X}_{\text {competency }}=\text { Practice }+ \text { Project }+ \text { Product }+ \text { Potofolio }+ \text { Written } \\
& N_{\text {competency }}=\left|\bar{X}_{\text {competency }}\right| \\
& N_{\text {competency }}=\mid(\text { KKM }) \mid
\end{aligned}
$$

On the assessment of knowledge aspect, the order of score calculation starts from the equation 1, where the each subject has at least one competency, and maximum of six competences. On each competency has score average of written score test, observation score, and score of assignment. Then on equation 2, when the score average of competency exceeds the minimum score of criteria (KKM), then the score of competency is taken from Equation 1. If 
the score average of competency is not greater than the score of the KKM, they have to follow remidial. And the score of competency will be counted is the score of the KKM as equation 7. The sore of each competency will be searched back and become a daily score as Equation 3. The total score of the merger between the knowledge aspect of daily score with the score of the midterm and final exams of the semester, where each score is multiplied by the weighting value is already determined by the subject teachers using the equation 4 .

For the assessment of skills aspects, such as in the aspect of knowledge has the same competences, consists of score of practice, score of project, score of product, score of portfolio and score of written test is formulated in equation 5. From the score of each competency will be searched the average and to be the daily score, and the total scores of the skills aspect is calculated by equation 3 where the daily score on skills aspect will be the total score.

The assessment results of the achievment of knowledge aspect and skills aspect presented in the form of numbers and description. Determination of KKM which should be achieved is done through the meeting of the Board of Educators. After all the assessment process is done, the score of all subjects in the aspects of knowledge and skills combined into the score collection (DKN).

To simplify the process, it have to change all to digitize process so that all the scores of the students who are given by subject teachers is accurate, timely when needed, and with a consistent format, then in this research built an application is named Siadhel (Eighteen information System). The application of Siadhel can help the principal, teachers, and students in providing information about academic that can be accessed easily, improving the quality of work of its institution education services, as supporting decision-making, as tools to solve the problems, and help the operational school organization [10]. In addition, the information gained from this applications to be the reference for the principal in making policies.

\section{RESULTS AND DISCUSSION}

\subsection{Requirement \& Analysis}

Collecting data and information directly on the location of the research by doing an interview to the academic section of the curriculum. Some conditions were found and faced in the process of collecting the students scores as follows:

1. The difficulty in directly change between an accumulated score from the subject teachers to the class teachers. It would need more time if happened an error of the scoring.

2. Almost happened many errors in the inputing score process form the subject teachers to the class teachers. Too much formula while using Microsoft Excel, will be made some difficulties to move to the Microsoft Excel format owned by class teachers, so it requires a longer time to process an appropriate score check.

3. The increase of the class teachers job while preparing the report, because of at the time of receiving the score collection from the subject teachers often changing the number in a single file, so need to recheck before printed.

4. The report which shown to the principals could not be directly provided and takes quite long time. It is because each class teacher has their different file format, when it made into a Microsoft Excel file that was given to the principle they have to remove the formulas first on the excel file own by class teachers, then copy and paste into the other excel file, it would need require time and a very high precision.

IJCCS Vol. 13, No. 3, July 2019 : 283 - 292 
From the existing condition already mentioned was obtained some functional needs system and non-functional system. Here are some functional system requirements:

1. The system can be opened by some types of browser and some operating systems setting.

2. This system can do input data of the students, teachers/staff, schedule, and students scores of the SMPN 18 Bekasi.

3. This system can display data of the students, teachers/staff, schedule, students scores of SMP 18 Bekasi.

4. This system provides the features of change and delete students data, teachers/staff, schedule, and students score of SMPN 18 Bekasi.

5. This system can display student reports of SMPN 18 Bekasi.

The Non functional needs system has developed are:

1. Can be accessed without user limit, within 24 hours ( 1 day)

2. The system/application created with the web responsive character, so can be opened not only through computer/PC, but can be opened through the mobile browser.

3. To maintain the security of the data, it gives the different levels right of access of the users (students, subject teachers/class teachers, the principal).

\subsection{Design \& Implementation}

At this stage, specify the image of the user who can access this application, as well as describing the processes undertaken by the respective user. Users has been determined to be 3 , namely students, teachers/class teachers, administrator, and the principal. Explaining process using the Unified Modeling Language (UML), including use case diagram, activity diagram, and class diagram.

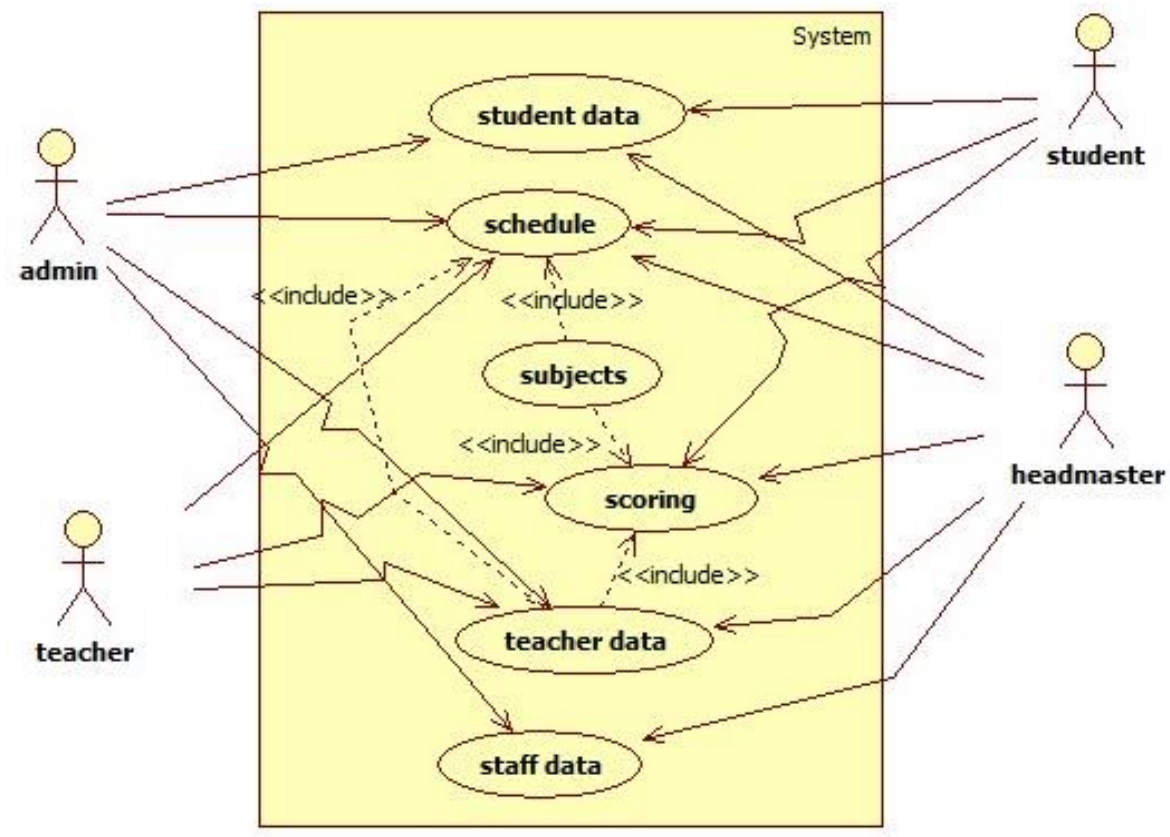

Figure 2 Use case diagram 
From Figure 2 above can be seen parts which are illustrated with a use case can be accessed by four actors or users. Part of the students only can see the students data, schedule, and view the scores that have been inputted by the teachers. Section of the teachers only can see data for teachers, schedules, as well as the students score inputted. Section admin can access the overall input, such as an update or delete, but about the students score the admin only can see, can not input it, change, or remove. The principal is given access only can see the entire contents of the information system which is created.

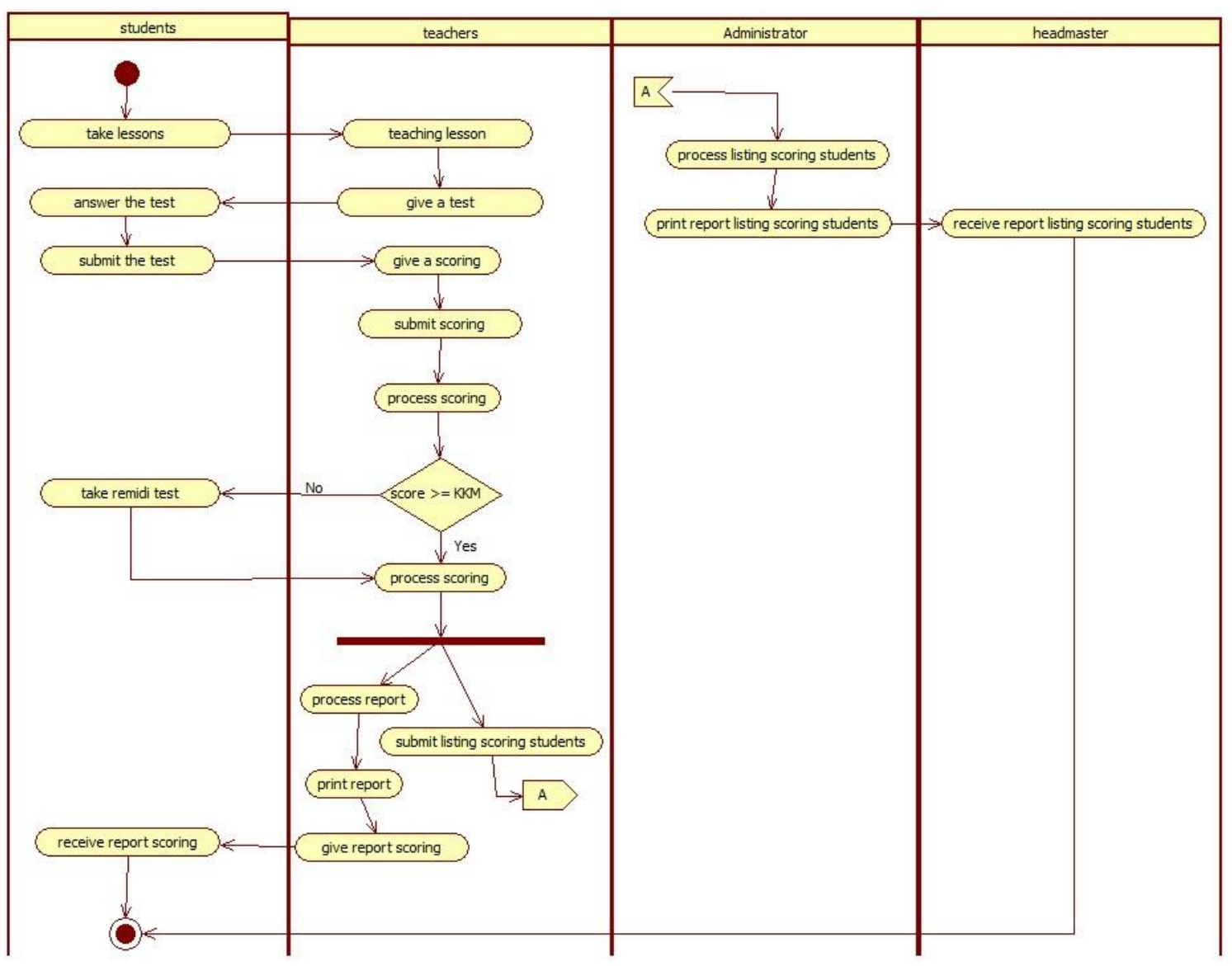

Figure 3 Activity Diagram

Figure 3 is an overview of the obtaining process of the valuation until finished as a list report and to be the reference of this information system, start while the students follow the lessons given by teachers. The teacher will give the test, which will be answered by the student and will be given a score by the teacher. Teachers manage the students score who have done their test, so that it can process the report and submit a list of the score collection's to the administration. The Administration section will provide in format report to be submitted to the principal for review regarding to the students scores. 


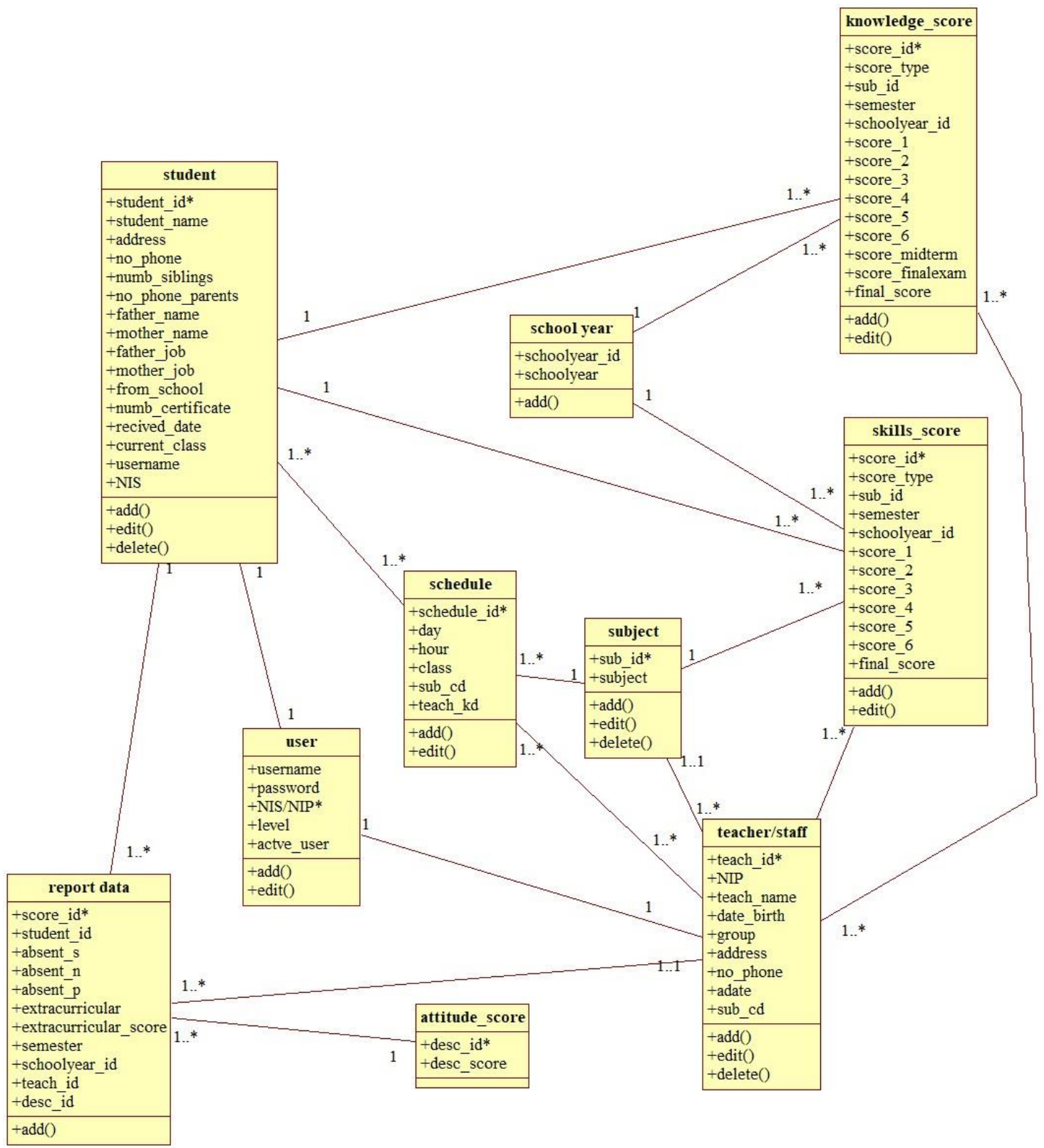

Figure 4 Class diagram

The database had been created is shown on Figure 4. Each of the table has an interrelated and has a relationship. Each table has a primary key, so it does not happen the redundancies data. Primary key will come up with random score so that facilitate the managing data in the internal school. Each entity has a rule of cardinality such as name of subject and teachers. Explanation of name of subject and teacher entity will establish a new entity namely the schedule. Between the entities of subject and teachers have a cardinality where one person of the teacher can teach one subject, and many teachers teach in a single subject.

Implementation of programming language code in the hypertext preprocessor (PHP) that will process the data and sending back to the webbrowser that will be HTML code [7]. So the HTML is also used as a language by PHP in describing the structure of website interface. In performing the implementation with PHP, it is necessary to install a webserver, so that it can 
ensure the website made with PHP and MySQL can be run on a client computer or server using the browser [8].

\subsection{Testing \& Deployment}

Basicly for testing the web can be accessed through the online network as well as local networks, and are widely accessible and there is also a desktop application which normally only accessible by desktop developed into web technologies. Later the desktop application can be accessed with a web browser like the web in general. However to access applications desktop required special web browser should provide API that are used framework to develop the application [11].

Siadhel applications can be opened on a wide range of web browsers by using a PC or mobile phone. In testing Siadhel application, done using the local server, and use Ngrok as a tool that works as a virtual private network (VPN). Illustration of the use of the Ngrok shown in Figure 5. Ngrok work opens the local server behind the NAT and firewalls by passing through a secure tunnel. By default will run HTTP tunnel as well as HTTPS tunnel. It works to change personal IP on the local server using virtual IP to be public IP, then public IP to be the reference of URL in access local server.

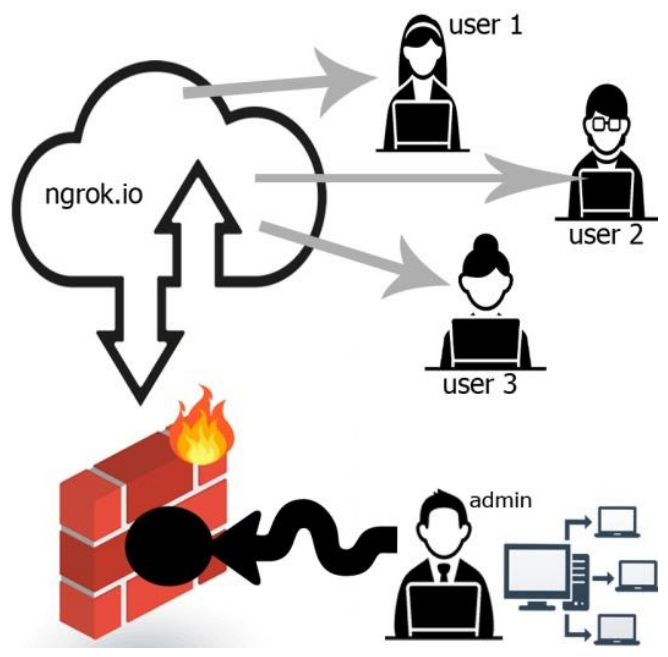

Figure 5 Ngrok using process

Black box testing carried out to know the qualities and weaknesses of the software which is being developed to further evaluated to do repairs in accordance with the functional requirements of the system that is supposed to be. At Siadhel the entire function on a button, or the provided options can run sending output according to given input. As the function of the login button, the function of a save button of the student data, button functions when input students score, and another buttons has been provided.

Siadhel deployment process does not use the Ngrok function, but rather through the hosting process, where the URL is certain and not changeable, not burdened with adequate memory needs that accessed by a lot of people, and can be accessed at various time without getting to know the time and numbers of users. After deployment process, do the test again using black box testing, the test results from black box testing figure on Table 1 .

Tabel 1 Result of the Black Box Testing

IJCCS Vol. 13, No. 3, July 2019: 283 - 292 


\begin{tabular}{|l|l|l|c|}
\hline \multicolumn{1}{|c|}{ Acivities } & \multicolumn{1}{|c|}{ Test Case } & \multicolumn{1}{|c|}{ Output } & Result Test Case \\
\hline $\begin{array}{l}\text { User login according to each level } \\
\text { (teachers, principal, } \\
\text { administrator) }\end{array}$ & $\begin{array}{l}\text { Enter } \\
\text { username } \\
\text { dan } \\
\text { password }\end{array}$ & $\begin{array}{l}\text { Displaying login for, } \\
\text { verification username } \\
\text { and password, enter to } \\
\text { first page of every level }\end{array}$ & Valid \\
\hline $\begin{array}{l}\text { Subject teachers/class teachers can do } \\
\text { some process of scoring students } \\
\text { management (view, delete, add, update) }\end{array}$ & $\begin{array}{l}\text { Inputting } \\
\text { students } \\
\text { score }\end{array}$ & $\begin{array}{l}\text { Access score data, } \\
\text { display scoring form, and } \\
\text { saving the inputted score }\end{array}$ & Valid \\
\hline $\begin{array}{l}\text { Users as Admin can do view, delete, } \\
\text { add, update in the students data }\end{array}$ & $\begin{array}{l}\text { updating } \\
\text { students data }\end{array}$ & $\begin{array}{l}\text { Access and display } \\
\text { students data }\end{array}$ & Valid \\
\hline $\begin{array}{l}\text { Users as Admin can do view, delete, } \\
\text { add, update on teachers and staffs data }\end{array}$ & $\begin{array}{l}\text { updating } \\
\text { teachers and } \\
\text { staffs data }\end{array}$ & $\begin{array}{l}\text { Access and display } \\
\text { teachers and staffs data }\end{array}$ & Valid \\
\hline $\begin{array}{l}\text { Users asa Admin can do view, delete, } \\
\text { add, update on the schedule data 1 }\end{array}$ & $\begin{array}{l}\text { updating } \\
\text { schedule } \\
\text { data }\end{array}$ & $\begin{array}{l}\text { Access and display } \\
\text { schedule data }\end{array}$ & Valid \\
\hline $\begin{array}{l}\text { Users as admin can do view, update on } \\
\text { the students score data }\end{array}$ & $\begin{array}{l}\text { updating } \\
\text { syudents } \\
\text { score data }\end{array}$ & $\begin{array}{l}\text { Access and display } \\
\text { students data }\end{array}$ & Valid \\
\hline Users can do update password & $\begin{array}{l}\text { Input and } \\
\text { save } \\
\text { password }\end{array}$ & $\begin{array}{l}\text { Access and display } \\
\text { change password form }\end{array}$ & Valid \\
\hline $\begin{array}{l}\text { User as Principal can do the process of } \\
\text { view the list of students scores in report } \\
\text { format }\end{array}$ & $\begin{array}{l}\text { Inputting } \\
\text { year and } \\
\text { semester of } \\
\text { the score } \\
\text { report }\end{array}$ & $\begin{array}{l}\text { Display } \\
\text { properly score data of the } \\
\text { students }\end{array}$ & Valid \\
\hline
\end{tabular}

\section{CONCLUSIONS}

An information system in the web form can be made with such of programming languages and varieties methods. In this research known that doing the web testing with the local server is not always directly tested with the local server PC. As already mentioned, in testing without directly related to local servers can use Ngrok. Ngrok change the personal IP on each PC is converted into virtual IP. With this virtual IP'S can access the local server directly without having to get in touch directly with the personal IP and passing through a tunnel safely without firewall and NAT. The lack of Ngrok is given a period of time to enable virtual IP to be the URL connecting to the local server. In addition, the URL provided is also only accessible by a single user, it cannot be shared by multiple users. For that must to do hosting, with hosting can have the permanent name of the URL, it does not need big capacity of the computer for saving, so can accessed by many users in the same time.

\section{REFERENCES}

[1] Djuandi, "Permendikbud Tentang Kurikulum Tahun 2013," Jun 2013 [online]. Available : http://bsnp-indonesia.org/2013/06/20/permendikbud-tentang-kurikulumtahun-2013/. [Accessed: 25-Maret-2019].

[2] F. Suryandani, Basori, dan D. Maryono, "PENGEMBANGAN SISTEM INFORMASI AKADEMIK BERBASIS WEB SEBAGAI SISTEM PENGOLAHAN NILAI SISWA DI SMK NEGERI 1 KUDUS," vol. X no. 1, hlm. 71-82, Jan 2017[online]. Available : https://jurnal.uns.ac.id/jptk/article/view/14976. [Accessed: 25-Mei-2019]

[3] Y. yan Sopian, "Desain dan Implementasi Sistem Informasi Akademik (Studi Kasus STAI Sebelas April Sumedang)," Jurnal Ilmu-ilmu Informatika dan Manajemen 
STMIK, vol. 12 No.12, Nov 2018 [online]. Available : https://www.academia.edu/38599143/Desain_dan_Implementasi_Sistem_Informasi_A kademik_Studi_Kasus_STAI_Sebelas_April_Sumedang?auto=download. [Accessed: 25-Mei-2019]

[4] D. Kurniadi dan A. Mulyani, "Implementasi Pengembangan Student Information Terminal (S-IT) Untuk Pelayanan Akademik Mahasiswa," Jurnal Algoritma STT Garut, vol. 13 No.1, hlm. 437-442 [online]. Avalilable : http://www.jurnal.sttgarut.ac.id/index.php/algoritma/article/view/399/364. [Accessed: 25-Mei-2019]

[5] R. T. Djaelangkara, R. Sengkey, dan O. A. Lantang, "Perancangan Sistem Informasi Akademik Sekolah Berbasis Web Studi Kasus Sekolah Menengah Atas Kristen 1 Tomohon," hlm. 86-04 [online]. Available : https://ejournal.unsrat.ac.id/index.php/elekdankom/article/view/8324. [Accessed: 25Mei-2019]

[6] DB-Engines, "DB-Engines Ranking," Jun 2019 [online]. Availabel : https://dbengines.com/en/ranking. [Accessed: 1-Juni-2019].

[7] M. A. AS dan N. A. Septiani, "PERANCANGAN SISTEM INFORMASI AKADEMIK MENGGUNAKAN METODE WATERFALL Studi Kasus: MADRASAHALIYAH AL-MANSYURIYAH KANZA MEKARJAYA TANGERANG," Jurnal Techno Nusa Mandiri, vol. XIII, No.2, Sep 2016 [online]. Available : http://ejournal.nusamandiri.ac.id/ejurnal/index.php/techno/article/view/316. [Accessed: 25-Mei-2019]

[8] S. H. Mulyani, "RANCANG BANGUN SISTEM INFORMASI SISTEM KREDIT PARTISIPASI AKTIVITAS MAHASISWA (SISKPAM)," Jurnal Sistem Informasi (JSI), VOL. 8, NO. 2, Oktober 2016, vol. 8 No.2, Okt 2016 [online]. Available : https://ejournal.unsri.ac.id/index.php/jsi/article/view/3643. [Accessed: 25-Mei-2019]

[9] E. Y. Anggraeni dan Ri. Irviani, PENGANTAR SISTEM INFORMASI. Yogyakarta: CV Andi Offset [online]. Available https://books.google.co.id/books?hl=id\&lr=\&id=8VNLDwAAQBAJ\&oi=fnd\&pg=PA $1 \& \mathrm{dq}=$ pengertian+sistem+informasi\&ots=eSUL4qeYLb\&sig=nF8Sv359p1qQCtx vnR V6ZRK23s8\&redir_esc=y\#v=onepage\&q=pengertian\%20sistem\%20informasi\&f=fals e. [Accessed: 25-Mei-2019]

[10] L. Ahmad dan Munawir, Sistem Informasi Manajemen: Buku Referensi. Jakarta: Lembaga Kita, $2018 \quad$ [online]. Available https://books.google.co.id/books?id=Jr2XDwAAQBAJ\&pg=PR2\&dq=pengertian+sist em+informasi\&hl=id\&sa=X\&ved=0ahUKEwif0Muxu7jiAhXm6nMBHekgCvkQ6AEI KTAA\#v=onepage\&q=pengertian\%20sistem\%20informasi\&f=false. [Accessed: 25Mei-2019]

[11] F. Adiputra dan K. Mustofa, "Purwarupa Framework Aplikasi Desktop Menggunakan Teknologi Web," IJCCS, Vol.9, No.1, January 2015, vol. 9, hlm. 23-32, 012015 [online]. Available : https://jurnal.ugm.ac.id/ijccs/article/view/6637/5185. [Accessed: 25-Mei-2019]

[12] V. JOHN dan H. DONE, PRINCIPLES AND PRACTICE OF SOFTWARE TESTING : INSIGHTS INTO TESTING. NEW DELHI: EDUCREATION PUBLISHING, 2018 [online]. Available https://books.google.co.id/books?id=X2J9DwAAQBAJ\&pg=PA50\&dq=testing+black +box\&hl=id\&sa=X\&ved=0ahUKEwjOczNjcbjAhUUSX0KHaxzBZ4Q6AEIKTAA\#v=onepage $\& \mathrm{q}=$ testing\%20black\%20box $\& \mathrm{f}=$ false. [Accessed: 25-Mei-2019]. 